original figure, but Walker's diagnosis is no different.

Orgyia sP. Packard.

I89o, Packard, $5_{\text {th }}$ rept. U. S. ent. comm., p. 774 .

Dr. Packard describes a larva appearing much like $O$. antiqua, but says: "It differs from $O$. leucostigma in having a pair of large prothoracic lateral black pencils" [besides the usual subdorsal ones?] and there are "three coral retractile warts." I would like to call particular attention to this form. It evidently differs structurally from any of the known North American Orgyia in having three instead of two retractile tubercles, besides apparently having two pairs of hair pencils on joint 2. It must be an undescribed species. The larvae were found on pine.

The following table will serve to distinguish the mature larvae of Orgyia.
Head red.

Warts pale yellow leucostigma S. \& A. Warts orange . . . inornata Beut. Head yellow . . . . definita Pack. Head black.

Without lateral tufts on joints 5 and 6 .

Pencil on joint 12 yellow, tufted with black . . . . vetusta Boisd.

Pencil on joint 12 black, perhaps preceded by brown.

Three yellow lines on each side gulosa $\mathrm{Hy}$. Ed.

Two yellow lines on each side. Warts bright crimson cana Hy Ed. Warts orange or yellowish badia $\mathrm{Hy} \mathrm{Ed}$.

With lateral tufts on joints 5 and 6 .

Two retractile tubercles antiqua $\mathrm{L}$.

Three retractile tubercles $s p$. Pack.

\title{
SYNOPSIS OF THE N. AMERICAN SPECIES OF MEGACILISSA.
}

\author{
BY WM. J. FOX, PHILAdELPHIA.
}

Labrum biridged, or strongly furrowed down the middle.

Wings not or but slightly fuscous apically. Abdomen dorsally, with exception of first segment entirely black, with black pubescence. . . electa Cr. $\delta$. Abdomen dorsally black, with the apical margins of segments 2-4 with white pubescence. . Tarrowi Cr. $\& \delta$.

Abdomen greenish, without white fasciae. . . mexicana $\mathrm{Cr}$. $q$.

Wings on apical half blue-black; legs reddish; abdomen black, on the sides, beneath and the sixth and seventh dorsal segments with fulvous pubescence. . . . gloriosa n. sp.

Labrum not ridged or furrowed, at the most swollen basally; abdomen fasciate; legs brownish, with brownish pubescence; wings with a yellow tinge eximia Sm. $\delta$.
Megacilissa gloriosa \%.-- Labrum with a long, narrow, medial furrow; clypeus with strong, close punctures, those in the middle confluent and forming transverse rugae; ocelli situated very low down, the anterior one separated but little from the hind margins of the clypeus and is connected with it by a furrow; vertex and cheeks with rather fine, close punctures, those on the cheeks finest and sparsest; first joint of flagellum fully as long or a little longer than the following five joints united, joints 2-5 shortest and about equal in length; tarsal claws armed with a long, acute tooth, in shape somewhat similar to the claw itself; dorsal abdominal segment finely and closely punctured, except apical portion of segments $1-4$, which is depressed and impunctate; enclosure on last dorsal segment strongly furrowed along the lateral borders. Black; tegulae and legs, except the four anterior femora in part, ferruginons; 
head (except a few nude places as the sides of front, top of vertex and thelabrum medially), the thorax densely, legs, dorsal segment one in front, and $\mathrm{I}-4$ on sides, the fifth and sixth entirely and the greater part of ventral segments, with dense fulvous or goldenochraceous pubescence, darkest on top of thorax; fore-wings on basal half sub-hyaline, or with a yellowish tinge, the apical half bluish-black, first recurrent nervure, uniting with the second transverse-cubital nervure, first submarginal cell the smallest, the third largest, marginal cell very long and narrow, hind wings subhyaline. Length, $22 \mathrm{~mm}$.

Las Cruces, N. Mex. (Aug. 2 I, C. H. Tyler Townsend). Will be at once distinguished by the extremely low position of the ocelli and the bluish-black wings.

Miscellaneous Notes.-The West African moths figured on Plate ro in the present number illustrate Dr. W.J. Holland's article; they are the following. Fig. I. Lomodonta erythrina; 2 . Heteronygmia stigmatica; $3 . \mathrm{H}$. argiloides; 4. H. clathrata; 5 . H. arctioides; 6. H. basibrunnea; 7. Laelia hypoleucis; 8 . L. ocellata ; 9. Aroa nigripicta ; ro. Dasychira sublutescens; I I D. ruptilinea; I2. D. congia Druce; I3. Aroa lata; I4. Heteronygmia hypoxantha; 15. H. rhodapicata; 16. Artaxa nigra; I7. Laelia lignicolor; r8. Euproctis Reutlingeri ; I9. Euproctidion Gabunica ; 20. Artaxa mesomelaena; 21 . A. parallela; 22. A. discipuncta; 23. A. palla; 24. A. melaleuca; 25. A. rotundata; 26. A. apicipuncta; 27. Balacra rubricincta; 28. B. glagoessa; 29. B. damalis; 30 . Casphalia nigerrima; 31 . Anace monotica; 32 . A. parachoria; 33 . Apisa cana; 34. Alpenus multiscripta.

In the line of J. B. Smith's studies on the mouth-parts of Diptera, Dr. S. W. Williston in the Kansas University quarterly for January describes these organs in the Apioceridae and allied families.

An illustrated and descriptive list of the galls, 88 in number, found in the vicinity of New York, is given by W. Beutenmüller in the Bull. Amer mus. nat. hist., v. 4; 42 are hymenopterous, 34 dipterous, II hemipterous and $I$ arachnidan.

Details of the anatomy of certain species of Orthoptera are given by J. B. Smith in Bull. 90 of the New Jersey experiment station.

\section{A. SMITH \& SONS, 114 FULTON STREET, New York. MANUFACTURERS AND IMPORTERS OF GOODS FOR EHTOMOLOGISTS, \\ Klaeger and Carlsbad Insect Pins, Setting Boards, Folding Nets, Locality and Special Labels, Forceps, Sheet Cork, Etc. Other articles are being added, Send for List.}

\section{The Butterflies of the Eastern United States and Ganada.}

With special reference to New England. By Samuel H. Scudder.

Illustrated with 96 plates of Butterflies, Caterpillars, Chrysalids, etc. (of which 4 I are colored) which include about 2,000 Figures besides Maps and Portraits. I958 Pages of Text.

Vol. r. Introduction; Nymphalidae.

Vol. 2. Remaining Families of Butterflies.

Vol. 3. Appendix, Plates and Index.

The set, 3 vols., royal 8vo, half levant, $\$ 75.00$ net.

HOUGHTON, MIFFLIN \& CO.,

4 Park St., Boston, Mass. 

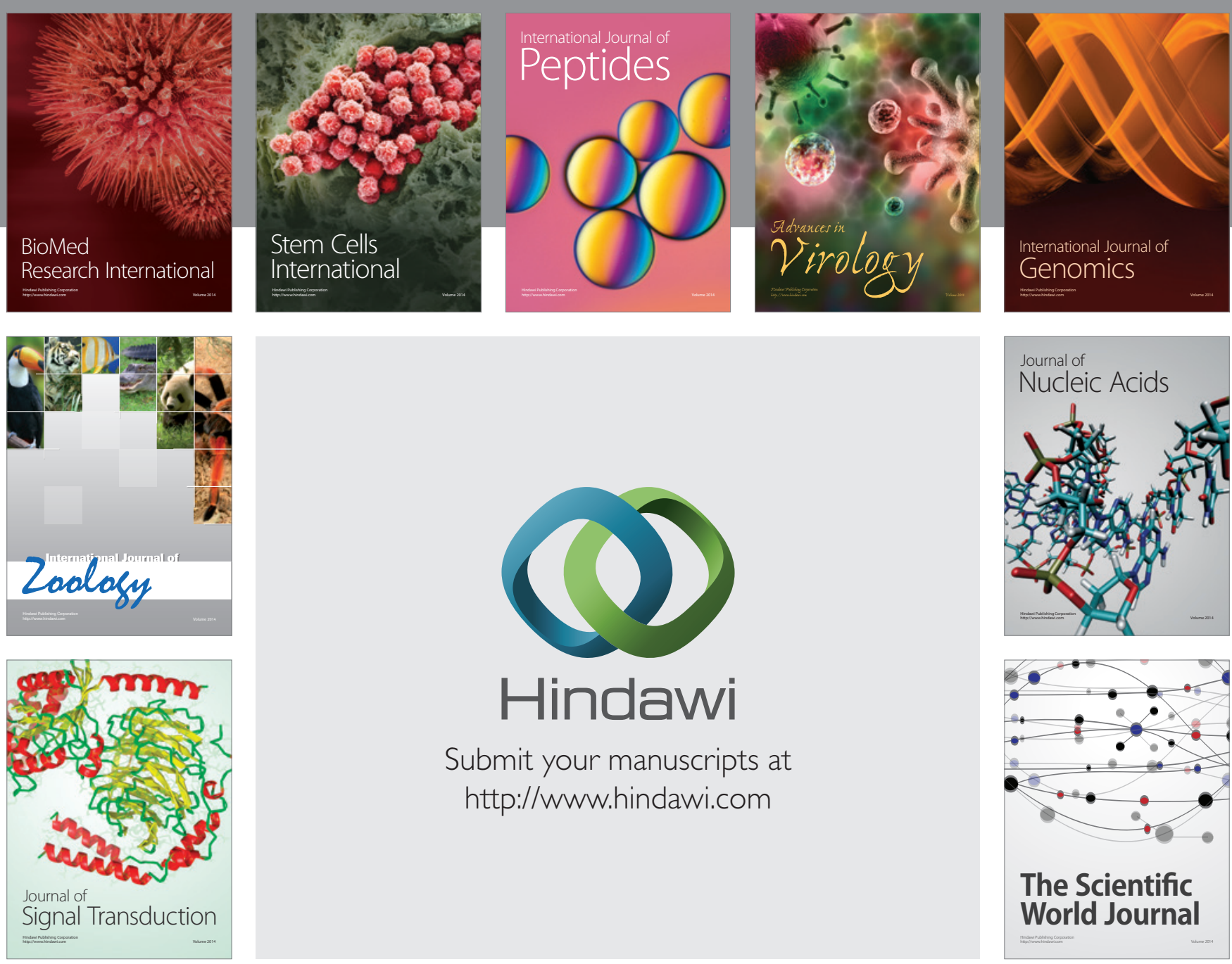

Submit your manuscripts at

http://www.hindawi.com
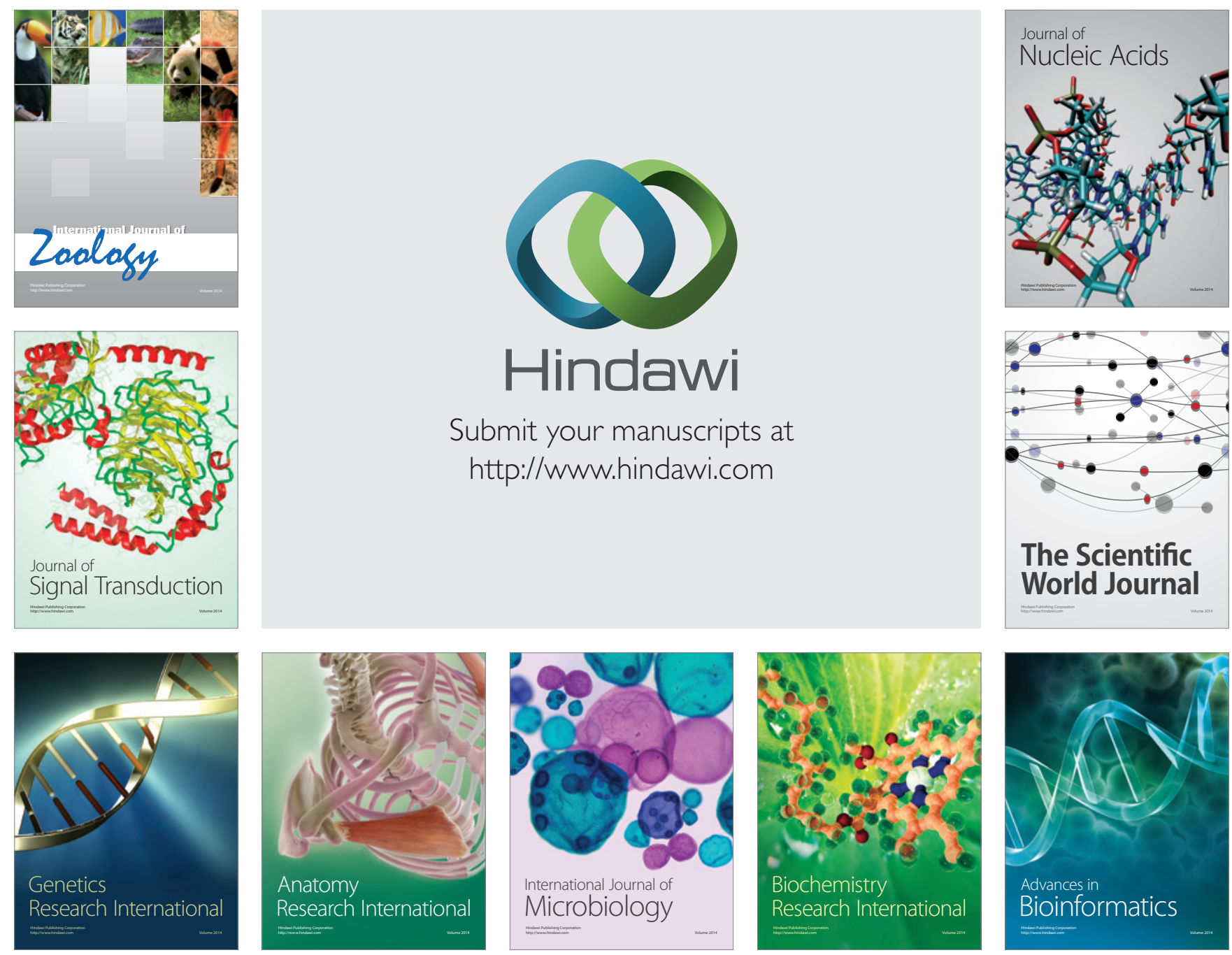

The Scientific World Journal
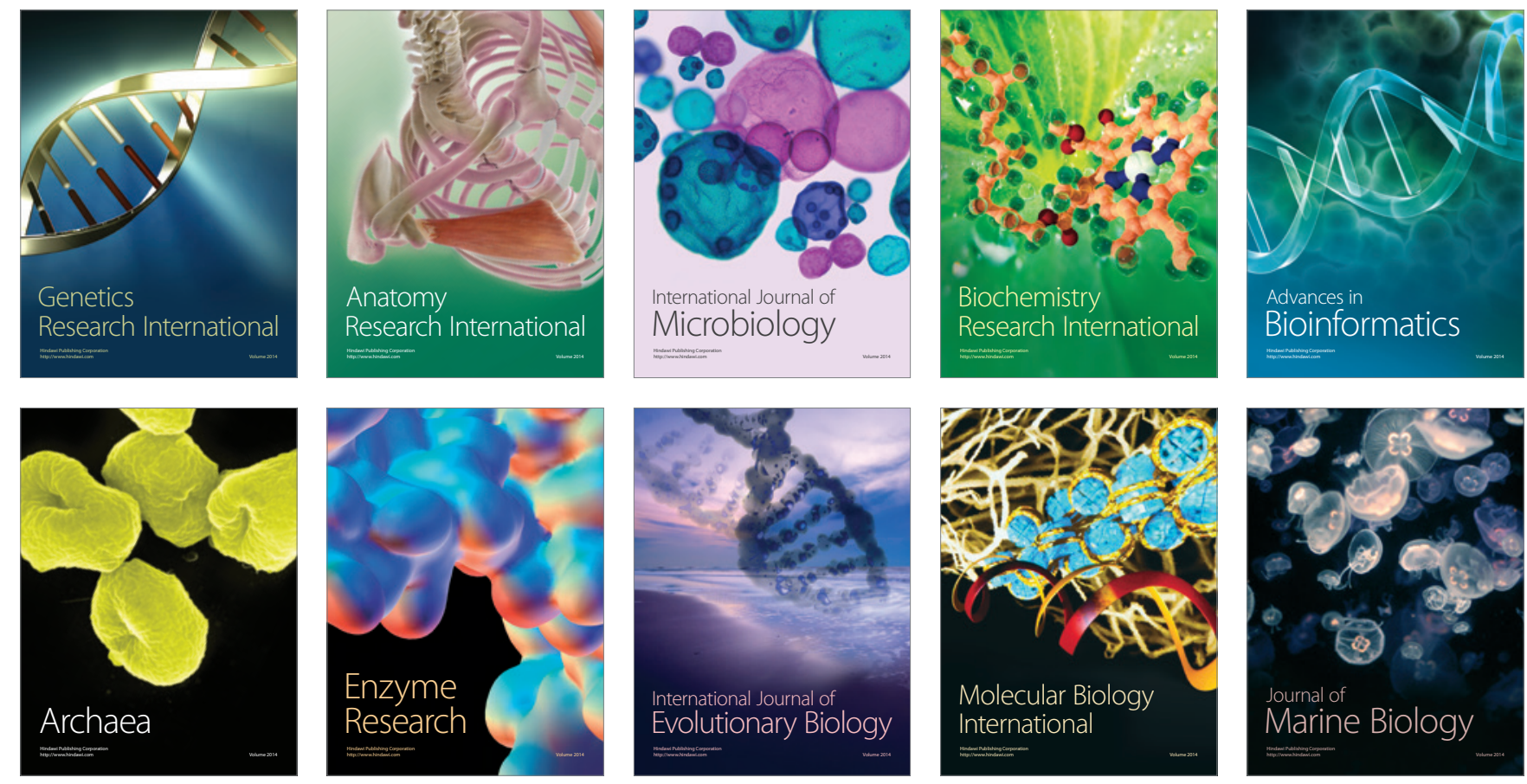